\title{
ПСИХОЛОГІЧНІ ПИТАННЯ ГЕРБАРТІАНСЬКОЇ ПЕДАГОГІКИ
}

Н. О. Федчишин

\author{
ДВНЗ “Тернопільський державний медичний університет імені І. Я. Горбачевського МОЗ України”
}

PSYCHOLOGICAL ANSWERS OF HERBARTIAN PEDAGOGIC

\author{
N.O. Fedchyshyn \\ SHEI "Ternopil State Medical University by I. Ya. Horbachevsky of MPH of Ukraine"
}

\begin{abstract}
У пропонованій статті аналізується вплив психології на педагогіку в поглядах одного з представників педагогічної течії гербартіанства (кінця XIX - першої половини XX ст.) К.-Ф. Стоя, розкривається зміст основних ідей вченого: репродукція загальних уявлень у свідомості, взаємодія розуму, набутих знань і вплив середовища; досліджується цінність його психологічних поглядів.
\end{abstract}

\begin{abstract}
The suggested article deals with the analysis of the influence of psychology on pedagogics in views of K. V. Stoy, one of the representatives of Herbartian pedagogical movement (the end of XIX - the first half of XX century). The content of the main ideas of the scientist is revealed: the reproduction of perception in consciousness, the interaction of intelligence, knowledge and influence of the environment. There have been investigated the value of K.V. Stoy's psychological views.
\end{abstract}

Вступ. В останнє десятиліття спостерігаємо такі корінні зміни в житті нашого суспільства, як: активна фаза реформування системи освіти, відновлення й забезпечення інтелектуального потенціалу нації, інтерактивність, людиноцентричність та проективність навчально-виховного процесу, інтеграція у світову освітню систему, конкурентоспроможність у будь-якій сфері, в тому числі інтелектуальній. Складний процес становлення й розбудови сучасної української освіти неможливий без урахування вже напрацьованого вітчизняного й зарубіжного досвіду, грунтовне вивчення, широке висвітлення й творче використання якого забезпечить дотримання принципів єдності, спадкоємності та наступності у розвитку педагогічної науки.

Знання психологічних основ навчання та виховання, їх структури та способів здійснення $€$ необхідним для розв'язання практичних завдань організації навчально-виховного процесу в цілому. Знання психологічних закономірностей $є$ вкрай необхідне при здійсненні процесу навчання (загальні закономірності взаємозв'язку і взаємозалежності змісту, форм та методів, тенденції формування вмінь і навичок). У своїй основі педагогіка та психологія органічно пов'язані між собою, й тому педагоги та психологи у співробітництві розв'язують питання діалектики навчання, розкривають можливості навчання у прискоренні цього розвитку. Багато вчених, які досліджували питання педагогічної психології, не згадували або й не розглядали (чи тільки частково) внесок та вплив педагогічного вчення гербартіанської педагогіки не лише на проблеми безпосереднього впливу психології на педагогіку, але й на розвиток психології взагалі.

Психологічним основам навчання і виховання багато уваги приділяли видатні вітчизняні та зарубіжні філософи, педагоги та психологи: Я. А. Коменський, Ж. Ж. Руссо, Й. Песталоцці, Й. Гербарт, А. Дістервег, Г. Сковорода, Дж. Локк, К. Ушинський та ін. Дана проблема була і надалі залишається цікавою як для вітчизняних та зарубіжних педагогів, так і для психологів (Г. Багір, А. Баумгартен, Д. Беннер, Д. Богоявленський, Л. Виготський, Г. Гаазе, Е. Гайслер, П. Гальперін, Г. Горнштайн, В. Давидов, Й. Дерболав, В. Ділтей, Г. Допп-Форвальд, Г. Дріш, В. Дювель, Д. Ельконін, Л. Занков, Г.-Ю. Іпфлінг, Г. Костюк, Г. Лаусберг, А. Леонтьєв, Ф. Лерш, К. Менце, Н. Менчинська, Г. Ноль, В. Панюшкін, С. Рубінштейн, Ф. Сандлер, Н. Тализіна та ін.).

В українській науці радянського періоду наукове надбання Й.-Ф. Гербарта та його школи з ідеологічних міркувань замовчувалося. Ситуація змінилася лише в останні два десятиріччя, коли на наукових симпозіумах в Ольденбурзі (Німеччина) була регенерована Спілка наукової педагогіки. В зазначений період німецькі вчені оприлюднили праці Й.-Ф. Гербарта та гербартіанців, публікації про його школу, які відображають окремі періоди та напрями їх діяльності. Немає потреби переконувати про значення

(C) Н. О. Федчишин 
психологічних творів Й. Гербарта і його послідовниківгербартіанців для всіх, хто цікавиться психологією чи педагогікою. Саме тому цікавими у цьому відношенні є погляди гербартіанця К.-Ф. Стоя.

Мета статті - аналіз змісту основних ідей психології гербартіанця Карла-Фолькмара Стоя (1815 1885). Для розгляду означеного питання слід виконати такі завдання: проаналізувати репродукцію загальних уявлень у свідомості та визначити взаємодію розуму, набутих знань і вплив середовища.

Основна частина. У 1870 р. К.-Ф. Стой опублікував "Психологію у стислому викладі" "Die Psychologie in gedrangter Darstellung" як посібник для читання лекцій та практичних занять у гімназіях, педагогічних семінаріях та університетах. У передмові було наведено думки щодо необхідності вивчення елементів психології у вищих навчальних закладах. К.-Ф. Стой констатував незнання студентами основ філософії й вимагав уводити в навчальний процес частково елементи логіки та психології як “зародки філософського інтересу” [6], щоб студенти могли пізніше через безпосередні відчуття пізнавального інтересу здогадатися про подальше вивчення пізнання. Для того щоб усунути сваволю емпіризму та матеріалізм (скасовує відмінності між духовним та фізичним) від психології, він дотримувався при викладенні загальної психології таких трьох положень метафізики, як: 1) основою всіх психічних феноменів є єдиний реальний носій; 2) внутрішньому стану душі можуть перешкоджати певні явища, проте не змінюватися й не стиратися; 3) одночасне виникнення психічних станів повертається до мотиву зв'язку та взаємодії, що є у душі.

В. Райн убачав у відчуттях найпростіший стан душі. Він назвав відчуття відповідно до їхнього виникнення та поведінки “простими уявленнями” й вказав на два основні класи: фізичні відчуття (голоду, спраги і т. п.) та органи чуття (нюх, зір, слух, смак, температурні, больові та інші відчуття). Якщо взяти до уваги, що в душі одночасно виробляється значна кількість відчуттів, то у поєднанні 3 досвідом К.-Ф. Стой виокремив такі чотири головні тези: 1) поєднання однакових відчуттів веде до єдності; 2) результатом поєднання гетерогенних відчуттів $\epsilon$ змішування; 3) поєднання протилежних відчуттів породжує спочатку відносні гальмування й згодом випадкові змішування; 4) зникнення причин гальмування дає безпосередню репродукцію гальмування. Перехід із стану гальмування у негальмівний чи навпаки вважається розглядом руху уявлень [2].

Під поєднанням уявлень К.-Ф. Стой розумів об'єднання негальмівних чи гальмівних елементів. Він розрізняв: 1) загальні уявлення, до яких відніс змішані гетерогенні прості уявлення; 2) ряди уявлень, які продукуються в результаті об'єднання уявлень; 3) маса уявлень, які утворюються через об'єднання чисельних загальних уявлень та рядів уявлень. Звідси він дійшов висновку, що: а) подібні загальні уявлення взаємодіють як однакові прості уявлення; б) загальні уявлення, які зустрічаються з гетерогенними простими уявленнями, об'єднується з подібними [3].

Результат процесу взаємодії загальних та протилежних уявлень, за К.-Ф. Стоєм, складається, з одного боку, із гальмування, а з іншого - із репродукції загальних уявлень. Гербартіанець розумів всю суперечність загальних уявлень як сприяння окремим елементам, які взаємодіють і можуть гальмуватися. Якщо елементи загальних уявлень можуть поєднуватися між собою, то намарним є відношення до ступеня ясності, в якій змішуються елементи загальних уявлень 3 рештою.

Загальмовані загальні уявлення можуть вивільнятися й повертатися у свідомість. Це відбувається безпосередньо не лише з простими уявленнями. За умови, коли до чи після гальмування два чи більше уявлень поєднуються між собою, то безпосередня репродукція у зрілому розумі викликає певні уявлення, які гальмуються на основі протилежності. Як наслідок репродукція була дієвою, коли ясність домінувала над об'єднанням. На його думку, такий процес чисельних безпосередніх репродукцій тісно пов'язаний із відповідним "змістом" та станом свідомості. Наявні обмеження та регулювання безпосередньої репродукції у свідомості зрілої людини гербартіанець не міг чітко пояснити із-за чисельних комплексних процесів. Під безпосередньою репродукцією він розумів основні умови, в яких розширюється розумовий кругозір і дієздатність уявлень. Взаємодія розуму, набутих знань та вплив навколишнього світу саме повертають до репродукції. Сюди він зарахував вживання символів, як наприклад, у мові. Ряди уявлень мають вплив на відтворення й залежать від виду, напряму та швидкості репродукованих частин. Під репродукцією К.-Ф. Стой розумів “еволюцію”, коли їі перший елемент спричиняє поступову репродукцію подальших й надалі говорив про “стан інволюції (зворотної діiі)" [3], коли відтворення кінцевого елемента викликає обмежену репродукцію цілого ряду й вважається одночасною. Гербартіанець наголосив, що успіх еволюції залежить від сильного зв'язку та незначної кількості елементів ряду. Він зазначив, що еволюція та інволюція можуть відбуватися одночасно. Закріплений певний елемент у свідомості веде 
через репродукцію до еволюції, що було названо К.-Ф. Стоєм як уявлення послідовності.

З метою попередження зміни суб'єктивної оцінки К.-Ф. Стой запропонував розглянути зміни як періодичні та одночасні. Мова йде про інволюцію, коли невпорядковані уявлення об'єднуються. Психічне запам'ятовування уявлень він відніс до відчуттів (зір, дотик) й таких репродукцій, котрі залишаються дієвими при формуванні і репродукції певних рядів. Так поступово утворюються, наприклад, назви місцевостей. Якщо зустрічається значна кількість рядів уявлень без попереднього зв' язку, то відразу відбувається "невідкладне об'єднання” чи гальмування і подальше “часткове об'єднання”. Гербартіанець мав на увазі низку рядів, коли ряди уявлень вступають у певний зв'язок і поєднуються між собою.

К.-Ф. Стой вважав, що увага та запам'ятовування опираються на відтворення низки рядів. Під цим він розумів поєднання взаємопов' язаних явищ, які відніс до пам'яті. Якщо репродукція низки рядів відбувається у попередньому порядку, то, відповідно, гербартіанець назвав цю низку рядів "вираженою” чи “запам'ятованою”. 3 огляду на швидкість, надійність, ясність, чистоту репродукції важливою $є$ різниця іiі складових. Об'єднання рядів уваги та пам'яті з іншими може привести до фальшування репродукцій, в яких К.-Ф. Стой убачав “природні” основи ясності для “частковості” пам'яті [1]. Коли низку груп чи складові рядів окремих елементів спонукають до репродукції, то як наслідок виникають поєднання уявлень, які переплітаються з попередніми уявленнями. Такі “утворення фантазіі” можуть бути абстракціями, детермінантами чи комбінаціями [1]. 3 позиції змісту і структури розумових уявлень гербартіанець вказав на духовний і фізичний вплив фантазії (сюди зарахував не лише частину пам'яті, але й національність, індивідуум чи вік). 3 репродукції низки груп можуть виявлятися, за К.-Ф. Стоєм, разом із процесами вигадування (фантазування) і процеси мислення та філософствування (абстрактного мислення) [там само]. У цьому процесі логічних зв'язків уявлень він виокремив такі ступені: спочатку виникає “обтічність", а слідом - "загострення відтворених розумових рядів” [1]. Гербартіанець описав логічне поняття як поєднання незмінних, постійних й суттєвих часткових уявлень, які виникають при не зовсім вдалих гальмуваннях окремих, випадково сприйнятих чи набутих. К.-Ф. Стой пояснював, що індивідуальні поняття формуються із загальних, які складають основу, а форми досвіду і категорії виникають під впливом суджень.
Гербартіанець пояснив “емпіричні судження” певним поєднанням уявлень, які грунтуються на викликаній суб' єктними та предикативними уявленнями “основі” й мав на увазі необхідність “логічних суджень”. Ця необхідність виникає через поєднання певних думок, коли на основі гальмувань відпадають несуттєві, непостійні чи випадкові часткові уявлення. Коли об'єднання запізнюється й призводить енергійною поведінкою до часткових уявлень, то наявними стають набуті розумові ряди, названі К.-Ф. Стоєм “силогізм" [1]. Гербартіанець пояснив "масу уявлень" як зв' язок великої кількості уявлень, які мають всупереч їх протилежності спільні ознаки. Кожну масу уявлень він розглядав крізь призму формування рядів. Гербартіанець наголошував на “боротьбі”, котра відповідає за природну структуру маси уявлень. Змістом і метою цієї боротьби були, на його переконання, приєднання і об'єднання нових елементів. Якщо попередні маси уявлень домінували над новими, наголошував послідовник Й.-Ф. Гербарта, то сама людина стає іншою [1].

Гербартіанець звернувся до “апперцепції” як до продовження та зміни до перцепції, а схильність до засвоєння назвав "апперцептивним інтересом" [4]. Внутрішню апперцепцію він пояснював не через сприйняття, а за допомогою розумово набутих уявлень. К.-Ф. Стой зробив акцент на внутрішній апперцепції як джерелі уявлень. Він розглядав самовпевненість як найвище абстрагування “уявного “я".

Прихильник Й.-Ф. Гербарта був переконаний, що душевний стан дитини залежить від взаємодії уявлень, йдеться про бажання, коли розум має бажання і відтворені уявлення (повернені та об'єднані) швидко розвиваються. К.-Ф. Стой зауважив, що уявлення наближає прагнення, яке досяжне і визначив його як бажання, сила та надійність якого залежать від змістовності відтворення. Розумне бажання він відніс до сповільненого завершення за посередництвом судження, які належать до апперцептивної маси уявлень і значно впливають на внутрішній процес бажання [5]. Якщо бажання необдумані, то апперцепція спричиняється до відновлення попереднього стану. Гербартіанець звернув увагу на те, що бажання, які вириваються назовні, основні принципи і положення зазнають поразки від апперцептивної маси уявлень.

Відчуття виникають тоді, коли два протилежні уявлення, ряди уявлень чи маси уявлень перебувають у стані невирішеної протидії. Мова йшла про те, що невирішена протидія викликає у душі неприємне відчуття утисків, допоки буде подоланий бар'єр і це спричинить бажане звільнення. “Суб’єктивні відчут- 
тя” виникають тоді, коли допоміжні уявлення більше не блоковані, а “об'єктивні” - при двосторонній підтримці чи гальмуванні у свідомості споріднених чи протилежних уявлень (естетичних, моральних), або коли у сфері інтелекту відчуття збуджують гармонію, контраст, дисгармонію.

К.-Ф. Стой з'ясував, що збудження - це потрясіння характеру, коли сприйняті або відтворені уявлення (ряди, маси) проникають у свідомість і наявна рівновага заважає уже існуючим уявленням. Велике значення гербартіанець надав впливу темпераменту, який може діяти на психічне й духовне здоров' я [5]. Різницю темпераментів він пояснював більшою чи меншою диспозицією відчуття і збудження. Так темперамент сангвініка (радісного) і меланхоліка (похмурого) тримається на відчуттях, а холерика (дратівливого) та флегматика (малорухомого) - на збудженні. К.-Ф. Стой зауважив, що при хворобі психіки збудження і протилежний вплив уявлень більше негативно впливатимуть один на одного.

\section{Лiтература}

1. Bliedner A. Stoy, Karl Volkmar / A. Bliedner // In: Encyklopadisches Handbuch der Padagogik. Herausgegeben von W. Rein, Jena, zweite Auflage, 8. - Band, Langensalza, 1910. $-1034 \mathrm{~s}$.

2. Schwenk B. Das Herbartverstandnis der Herbartianer. Gottinger Studien zur Padagogik / B. Schwenk. - Weinheim, 1963. - $176 \mathrm{~s}$.

3. Stoj K. V. Philosophische Propadeutik. Gedrangte Darstellung der philosophischen Probleme der Logik und
Висновки. Гербартіанців сприймали як солідну наукову спілку, яка захищала своє власне бачення певних педагогічних та психологічних проблем: загальмовані загальні уявлення можуть вивільнятися й повертатися у свідомість, а негативні емоції-витіснятися у підсвідомість, взаємодія розуму, набутих знань та вплив навколишнього світу повертають до репродукції і т. п. К.-Ф. Стой, Т. Ціллєр, В. Райн розробили специфічні методи дослідження та форми організації, піклувалися про наукове зростання та можливе дальше поширення своїх ідей. Водночас гербартіанці намагалися винести певні питання на відкриті дискусії. Їхні погляди мали успіх, оскільки по-новому інтерпретувалися й були задіяні у вирішенні проблемних питань. Ураховуючи, що здебільшого конструктивні ідеї та педагогічний досвід Й.-Ф. Гербарта і його школи все ще не актуалізовані, їх творче застосування у подальшому сприятиме реформуванню системи національної освіти України загалом, забезпечуватиме і належну фахову підготовку сучасної генерації.

Psychologie/K. V. Stoj. -2 Bde. 1. Aufl. Leipzig 1870.-S. 251. 4. Stoj K. V. Psychologisch-padagogische Analysen / K. V. Stoj // In ASZ . - 1874. - B. 51. - S. 75-76; 101-103.

5. Stoj K. V. Psychologisch-padagogische Studien. Altes und Neues / K. V. Stoj. // In ASZ . - 1880. - B. 57. - S. 105-106.

6. Stoj K. V. Die Psychologie in gedrangter Darstellung. Leitfaden fur Vortrage und Studien aufGymnasien / K. V. Stoj. - Seminarien und Universitaten Darmstadt und Leipzig 1870. -S. 163. 